\title{
Lead and iron contents in parsley being cultivated in the area of Chrzanów geochemical anomaly
}

\author{
Paweł Mundała ${ }^{1}$, Artur Szwalec ${ }^{1}$, Renata Kędzior ${ }^{1}$, Marek Telk ${ }^{1}$, Marta Machaj² \\ ${ }^{1}$ University of Agriculture in Krakow, Department of Ecology, Climatology and Air Protection; \\ al. Mickiewicza 24/28,30-059 Kraków, Poland; e-mail:rmmundal@cyf-kr.edu.pl \\ ${ }^{2}$ University of Agriculture in Krakow, Department of Ecology, Climatology and Air Protection (master's student)
}

(C) 2014 Authors. This is an open access publication, which can be used, distributed and reproduced in any medium according to the Creative Commons CC-BY 4.0 License requiring that the original work has been properly cited.

Received: 30 December 2014; accepted: 28 January 2015

\begin{abstract}
Selected research polygon is located in Trzebinia commune in the mid of the $80 \mathrm{~km}$ way from Kraków to Katowice (the Upper Silesia capitol). The towns of Trzebinia, Chrzanów within the towns of Krzeszowice, Jaworzno, Mysłowice, have been creating a base of well-connected Kraków-Upper Silesia agglomeration. The inhabitants of Trzebinia commune are flexible on labour market, often commute to work in Kraków or Katowice. They have detached houses with gardens of one or two acres size, where "home-made", fresh, low-processed food could be produced. At the same time the area of Trzebinia Community belongs to Chrzanów geochemical anomaly, which is reflected in high values of cadmium, lead and zinc contents in the soils. This is the result of both natural and anthropogenic factors. The purpose of the paper was to evaluate lead and iron contents in roots and leaves of parsley being cultivated within the area of the anomaly. Considering, there is a positive geochemical anomaly, the lead contents in soil were low - the average value was $88.67 \mathrm{mg} \cdot \mathrm{kg}^{-1} \mathrm{~d}$.m. and only two contents 218.98 and 119.35 exceeded $100 \mathrm{mg} \cdot \mathrm{kg}^{-1} \mathrm{~d} . \mathrm{m}$. On the other hand the lead contents in parsley roots were high, many times higher than the allowable values. The lead contents in parsley leaves were also high. Phytoaccumulation indices low, only one had the average value, but at their minimal range (1.02 and 10.3 adequately for leaves and roots). Translocation index of lead was close to one. The iron contents in soils were not high and fall within the scope of low and average ranges that occur in Polish soils. The iron contents in leaves were high, attractive from nutrition point of view.
\end{abstract}

Keywords: parsley, geochemical anomaly, food quality

\section{INTRODUCTION}

Suburban areas of big cities in Poland have been witnessing a construction boom for the last three decades. Apart from lower prices, more privacy, peace and quiet another advantage of suburbs is the possibility of having a detached house with a garden, where within a couple acres "home-made", fresh, low-processed food could be produced. Trzebinia, Chrzanów, Krzeszowice and Jaworzno communes, which are located between Kraków and Katowice and have an easy access to both of these cities, are examples of such areas.
According to politicians and urban planners soon there might be the Silesian-Kraków urban agglomeration. Although it should be remembered, the area is located within the area of geochemical anomaly which occurs from Chrzanów and Olkusz in the east to Bytom and Tarnowskie Góry in the west (Lis \& Pasieczna 1995a, 1995b). This anomaly is reflected in high values of heavy metals contents, especially cadmium, lead and zinc, in the soils of this region. This is the result of both natural and anthropogenic factors. A local limestone which occurs here is ore-bearing. Mining and metallurgy of non-ferrous metals have a long 
(even thousand years old) tradition in this region (Kiryk 1995). As a result of mining and metallurgy of lead and zinc there was a great negative human impact on the environment, which changed through the centuries.

The purpose of the paper was to evaluate lead and iron contents in roots and leaves of parsley being cultivated in soils of Trzebinia Commune, which is located in the area of geochemical anomaly.

\section{METHODS}

The test areas have been monitored since 1993, the soil and crops have been analysed for heavy metal contents. The localization of test areas depended on: the general recognition of soil and crop state, the structure of land use, landforms as well as location and type of settlement. All tested areas were home vegetable gardens with different surface area, which varied from one to two acres. The spread of chosen areas were random with in the farmland of Trzebinia Commune (Fig. 1). The last selecting reason was a way of leaving of the people, the gardens owner. They were not farmers but farmers' children or grandchildren. They have families, houses, gardens. They were working outside their villages. The home gardens were the way to reduce family food costs and rest working in the garden. There were eleven areas fulfilling the requirements.

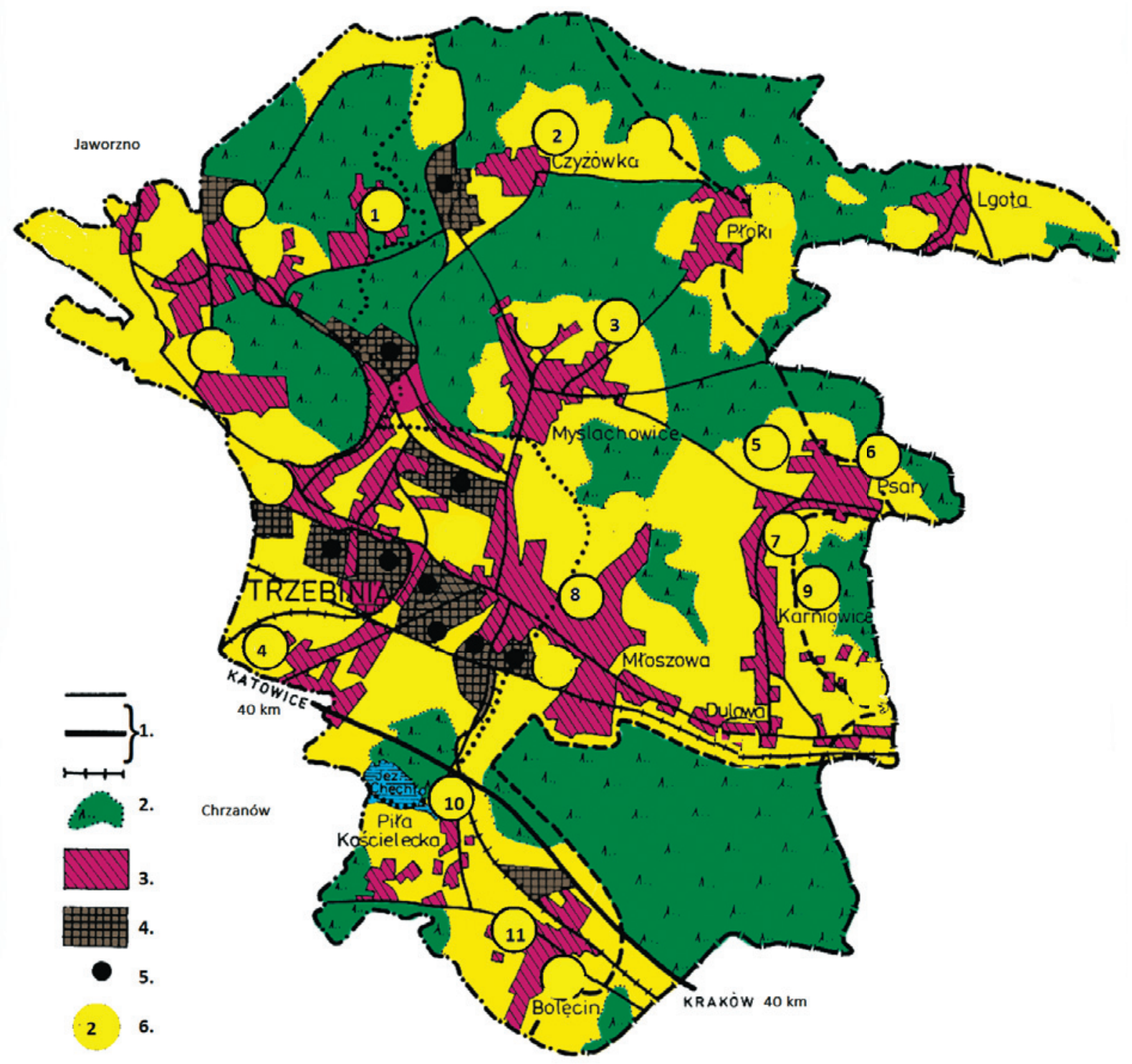

Fig. 1. A map of Trzebinia Commune with the: 1 - roads, 2 - forest, 3 - human settlements, 4, 5 -industrial areas and local metal sources, 6 - sampling areas (the gardens) 
The major agricultural characteristic of the gardens are as following: the vegetables were cultivated under a crop rotation practice, fertilization was mineral-organic, organic or mineral, never exceeded $150 \mathrm{~kg} \cdot \mathrm{ha}^{-1}\left(\mathrm{~N}+\mathrm{P}_{2} \mathrm{O}_{5}+\mathrm{K}_{2} \mathrm{O}\right)$, parsley varieties were chosen freely but the cultivation period was the same. The garden was a research area. Due to crop rotation principle one the fourth part of the garden was seeded with the parsley. Every year the next one. The samples of roots and leaves were collected yearly, in duplicate, from 2009 to 2012 in the beginning of September. Five $0.5-\mathrm{m}$ length sections of parsley rows were research point, they were chosen in a random way. Samples were taken from each section. A sample weight was about $5 \mathrm{~kg}$. In the research area two research points were established. In a laboratory samples were carefully washed in tap water than separated into leaves and roots. The next step was homogenization of the sample, separately roots and leaves. The fresh mass (f.m.) of the sample was reduced to about $800 \mathrm{~g}$ for leaves and about 500 g roots. Samples were weight and then were dried for four hours in a fan-assisted oven initially at $50^{\circ} \mathrm{C}$, followed by $100^{\circ} \mathrm{C}$. Weight after became cool in order to determinate dry matter (d.m.). The plant material was ashed. The process was run in a muffle furnace at $460^{\circ} \mathrm{C}$, twice (8 then 6 hours), applying a burnt-out operation with a concentrated $\mathrm{HNO}_{3}$ and extraction with $\mathrm{HCl}$. Every sample was mineralised twice.

The soil material was collected once in end of September 2009 year, when the parsley was collected. Topsoil (0.0-0.2 m) was sampled. A mixed sample consisted of a 10 individual soil sample taken by a soil probe. After homogenization in a plastic bucket a mixed sample about $0.5 \mathrm{~kg}$ of topsoil was taken. The sampling was repeated four times. In the laboratory soil was dried on air for several days. After being grounded and sieved samples were digested with a mixture of concentrated $\mathrm{HClO}_{4}$ and $\mathrm{HNO}_{3}$ acids. $\mathrm{HCl}$ was the extraction agent. All methods were taken from Ostrowska et al. (1991).

Lead and iron contents determination was carried-out by atomic absorption spectrometry method using a Solaar M6 spectrophotometer (Unicam).

\section{RESULTS}

Iron is a micronutrient, which means it is a component necessary for the development and functioning of every organism. Its content is considered in the context of: deficiencies in plants, animals and humans as well, nutritional value of food or its physiological functions. In case of human health there are rare cases of iron poisoning, which are the result of mineral food supplements overdoses or iron metabolism disorders that are due to genetic defects. Almost 2/3 of iron in the human organism is in the form of hemoglobin. Vegetables are the source of non-heme iron, which is harder for the body to absorb (Jędrzejaczak 2004). Plants have different contents of this micronutrient that depend on vegetation phase and their morphological parts (Kabata-Pendias \& Pendias 2002). Iron is not considered as a food contamination in law terms (Commission Regulation... 2011).

The iron contents in the tested parsley were (Tab. 1): for leaves: from 35.8 to $268.2 \mathrm{mg} \cdot \mathrm{kg}^{-1} \mathrm{~d} . \mathrm{m}$. with arithmetic mean of $156.20 \mathrm{mg} \cdot \mathrm{kg}^{-1} \mathrm{~d} . \mathrm{m}$. and for roots: from 30.56 to $111.96 \mathrm{mg} \cdot \mathrm{kg}^{-1}$ d.m., with arithmetic mean of $59.68 \mathrm{mg} \cdot \mathrm{kg}^{-1} \mathrm{~d} . \mathrm{m}$.

According to the World Health Organization a daily iron requirement for an adult is 10 or $15 \mathrm{mg}$ Fe (man or woman) (Bielecka et al. 2009). Considering that the mean of iron content in the tested parsley roots was $59.68 \mathrm{mg} \cdot \mathrm{kg}^{-1} \mathrm{~d} . \mathrm{m}$., $177 \mathrm{~g}$ d.m. (man) and $251 \mathrm{~g} \mathrm{d.m}$. (woman) of this vegetable should be consumed daily. Assuming, dry mass content in a root is $22.86 \%$ (Tab. 2), $735 \mathrm{~g}$ (man) and $1102 \mathrm{~g}$ (woman) of fresh parsley root should be consumed daily. In these simple calculations it was assumed that $100 \%$ of iron is being absorbed, in reality it is not higher than 5 to $10 \%$. The estimated amounts of roots fresh mass must be 10 to 20 times higher. Nobody consumes this vegetable daily in such amounts, so it can be stated, the parsley root was not a basic or even secondary source of iron for the citizens of Trzebinia Commune. In Poznan the tests were carried out in order to analyse the micronutrient content in parsley sold in supermarkets. The average iron content in a root was $57 \mathrm{mg} \cdot \mathrm{kg}^{-1} \mathrm{~d}$.m. (Bosiacki \& Tyksiński 2009) and it was a value comparable with the mean determined for the parsley in Trzebinia. 
Table 1

Contents of iron \& lead in leaves (l) and roots (r) of parsley and in soils. Phytoaccumulation indices (PI) \& Translocation insides (TI) as well

\begin{tabular}{|c|c|c|c|c|c|c|c|c|c|c|c|}
\hline Localisation & 1 & 2 & 3 & 4 & 5 & 6 & 7 & 8 & 9 & 10 & 11 \\
\hline \multicolumn{12}{|c|}{$\mathrm{Fe}$} \\
\hline \multicolumn{12}{|c|}{$\left[\mathrm{mg} \cdot \mathrm{kg}^{-1}\right.$ d.m. $]$} \\
\hline 09 (l) & 242.49 & 161.53 & 174.26 & 88.25 & 193.45 & 268.20 & 148.7 & 203.58 & 143.13 & 171.54 & 35.80 \\
\hline $10(\mathrm{l})$ & 194.26 & 141.35 & 168.95 & 83.49 & 162.34 & 205.30 & 133.8 & 220.69 & 133.44 & 152.98 & 47.80 \\
\hline $11(\mathrm{l})$ & 192.91 & 150.68 & 181.39 & 98.24 & 161.38 & 220.35 & 112.6 & 198.99 & 113.95 & 133.55 & 49.80 \\
\hline $12(\mathrm{l})$ & 201.34 & 163.11 & 165.83 & 96.37 & 186.36 & 245.68 & 138.2 & 211.87 & 164.99 & 165.47 & 44.60 \\
\hline mean & 207.75 & 154.17 & 172.61 & 91.59 & 175.88 & 234.88 & 133.33 & 208.78 & 138.88 & 155.89 & 44.50 \\
\hline $09(\mathrm{r})$ & 44.95 & 30.56 & 99.58 & 50.93 & 44.69 & 42.18 & 63.94 & 67.14 & 67.97 & 71.35 & 41.53 \\
\hline $10(\mathrm{r})$ & 54.36 & 33.16 & 101.36 & 48.15 & 43.13 & 47.39 & 70.98 & 79.23 & 72.43 & 68.11 & 53.69 \\
\hline $11(\mathrm{r})$ & 59.35 & 31.26 & 111.96 & 50.12 & 52.76 & 45.59 & 83.43 & 69.98 & 85.99 & 65.98 & 37.96 \\
\hline $12(\mathrm{r})$ & 52.18 & 33.04 & 99.46 & 49.35 & 49.28 & 43.67 & 52.97 & 75.98 & 71.26 & 70.48 & 37.21 \\
\hline mean & 52.71 & 32.01 & 103.09 & 49.64 & 47.47 & 44.71 & 67.83 & 73.08 & 74.41 & 68.98 & 42.60 \\
\hline topsoil & 7824 & 4125 & 8236 & 1811 & 11048 & 10417 & 14493 & 6079 & 8011 & 10678 & 20663 \\
\hline \multicolumn{12}{|c|}{ Value } \\
\hline PI(l) & 0.027 & 0.037 & 0.021 & 0.051 & 0.016 & 0.023 & 0.009 & 0.034 & 0.017 & 0.015 & 0.002 \\
\hline $\mathrm{PI}(\mathrm{r})$ & 0.007 & 0.008 & 0.013 & 0.027 & 0.004 & 0.004 & 0.005 & 0.012 & 0.009 & 0.006 & 0.002 \\
\hline TI & 3.94 & 4.82 & 1.67 & 1.85 & 3.71 & 5.25 & 1.97 & 2.86 & 1.87 & 2.26 & 1.04 \\
\hline \multicolumn{12}{|c|}{$\mathrm{Pb}$} \\
\hline \multicolumn{12}{|c|}{$\left[\mathrm{mg} \cdot \mathrm{kg}^{-1}\right.$ d.m.] } \\
\hline 09 (l) & 6.43 & 4.52 & 4.25 & 7.23 & 4.25 & 4.83 & 5.84 & 5.17 & 4.12 & 5.03 & 3.39 \\
\hline $10(\mathrm{l})$ & 5.86 & 5.11 & 3.56 & 4.84 & 6.57 & 4.01 & 4.68 & 6.25 & 3.52 & 4.69 & 3.17 \\
\hline $11(\mathrm{l})$ & 5.18 & 4.95 & 3.18 & 5.59 & 3.19 & 4.03 & 4.61 & 6.32 & 3.52 & 2.73 & 2.64 \\
\hline 12 (l) & 4.95 & 5.33 & 3.48 & 5.01 & 5.09 & 3.69 & 3.52 & 5.29 & 3.11 & 4.68 & 2.51 \\
\hline mean & 5.61 & 4.98 & 3.62 & 5.67 & 4.78 & 4.14 & 4.66 & 5.76 & 3.57 & 4.28 & 2.93 \\
\hline $09(\mathrm{r})$ & 6.41 & 4.83 & 4.25 & 7.45 & 5.26 & 4.87 & 5.49 & 5.19 & 4.08 & 5.16 & 3.59 \\
\hline $10(\mathrm{r})$ & 6.07 & 5.15 & 3.59 & 4.75 & 5.82 & 4.91 & 4.78 & 5.98 & 3.83 & 4.58 & 3.17 \\
\hline $11(\mathrm{r})$ & 5.01 & 4.92 & 3.17 & 4.06 & 3.11 & 4.35 & 4.35 & 5.98 & 3.51 & 2.91 & 2.64 \\
\hline $12(\mathrm{r})$ & 5.25 & 5.16 & 3.38 & 3.98 & 4.39 & 4.21 & 3.19 & 5.32 & 3.12 & 2.59 & 2.56 \\
\hline mean & 5.69 & 5.02 & 3.60 & 5.06 & 4.65 & 4.59 & 4.45 & 5.62 & 3.64 & 3.81 & 2.99 \\
\hline topsoil & 85.34 & 48.72 & 96.56 & 218.98 & 52.34 & 119.35 & 55.25 & 93.26 & 55.26 & 80.29 & 69.98 \\
\hline \multicolumn{12}{|c|}{ Value } \\
\hline PI (l) & 0.066 & 0.102 & 0.037 & 0.026 & 0.091 & 0.035 & 0.084 & 0.062 & 0.065 & 0.053 & 0.042 \\
\hline PI (r) & 0.067 & 0.103 & 0.037 & 0.023 & 0.089 & 0.038 & 0.081 & 0.06 & 0.066 & 0.047 & 0.043 \\
\hline TI & 0.99 & 0.99 & 1.01 & 1.12 & 1.03 & 0.90 & 1.05 & 1.02 & 0.98 & 1.12 & 0.98 \\
\hline
\end{tabular}


Table 2

Dry matter contents in leaves $(l)$ and roots ( $r$ ) of parsley cultivated in a geochemical anomaly

\begin{tabular}{|l|c|c|c|c|c|c|c|c|c|c|c|c|}
\hline Localisation & $\mathbf{1}$ & $\mathbf{2}$ & $\mathbf{3}$ & $\mathbf{4}$ & $\mathbf{5}$ & $\mathbf{6}$ & $\mathbf{7}$ & $\mathbf{8}$ & $\mathbf{9}$ & $\mathbf{1 0}$ & $\mathbf{1 1}$ \\
\hline \multicolumn{9}{|c|}{$[\%]$} \\
\hline $09(\mathrm{l})$ & 14.71 & 15.23 & 17.20 & 16.58 & 14.24 & 15.24 & 16.65 & 15.24 & 14.98 & 15.98 & 16.15 \\
\hline $10(\mathrm{l})$ & 14.89 & 15.48 & 17.01 & 17.21 & 14.78 & 15.29 & 16.98 & 15.98 & 14.68 & 16.47 & 16.97 \\
\hline $11(\mathrm{l})$ & 15.24 & 14.65 & 16.58 & 16.24 & 14.39 & 16.17 & 16.98 & 16.54 & 14.73 & 16.53 & 16.13 \\
\hline $12(\mathrm{l})$ & 14.26 & 14.07 & 16.14 & 15.98 & 15.11 & 15.09 & 16.14 & 16.42 & 15.24 & 16.98 & 16.46 \\
\hline mean & 14.78 & 14.86 & 16.73 & 16.50 & 14.63 & 15.45 & 16.69 & 16.05 & 14.91 & 16.49 & 16.43 \\
\hline $09(\mathrm{r})$ & 21.36 & 22.35 & 24.78 & 20.39 & 22.36 & 25.32 & 22.37 & 21.63 & 21.46 & 22.35 & 23.68 \\
\hline $10(\mathrm{r})$ & 22.68 & 22.48 & 25.32 & 21.65 & 22.11 & 24.44 & 21.59 & 22.14 & 22.78 & 23.11 & 23.99 \\
\hline $11(\mathrm{r})$ & 23.15 & 23.98 & 24.11 & 20.98 & 21.65 & 24.36 & 21.89 & 22.67 & 23.63 & 23.56 & 24.25 \\
\hline $12(\mathrm{r})$ & 25.14 & 21.98 & 23.58 & 21.30 & 21.99 & 23.56 & 23.12 & 21.96 & 21.77 & 22.98 & 23.78 \\
\hline mean & 23.08 & 22.70 & 24.45 & 21.08 & 22.03 & 24.42 & 22.24 & 22.10 & 22.41 & 23.00 & 23.93 \\
\hline
\end{tabular}

The content of this micronutrient in a root of parsley grown in a soil contaminated with heavy metals from non-ferrous metals mining in Romania (Harmanescu et al. 2011) was even $950 \mathrm{mg} \cdot \mathrm{kg}^{-1} \mathrm{~d} . \mathrm{m}$. Whereas a reference value (given by the same authors), determined for plants grown in uncontaminated soils was $210 \mathrm{mg} \cdot \mathrm{kg}^{-1} \mathrm{~d} . \mathrm{m}$. These contents exceed the values obtained in Trzebinia many times (from 4 to 16 times). Much lower contents (3.46-6.18 mg.kg ${ }^{-1} \mathrm{~d} . \mathrm{m}$.) in a root of parsley grown conventionally, ecologically and in allotments were determined by Śmiechowska \& Florek (2011). Similarly the contents for parsley bought at a market in Jerusalem were less than half of the determined in Trzebinia values and equalled on average $25 \mathrm{mg} \cdot \mathrm{kg}^{-1} \mathrm{~d}$.m.

The average iron content in the leaves of parsley grown in Trzebinia Commune is $156.20 \mathrm{mg} \cdot \mathrm{kg}^{-1} \mathrm{~d} . \mathrm{m}$. and it is over 2.6 times higher than the content in roots. About 64 or $94 \mathrm{~g}$ of dried leaves of tested parsley (about 406-609 g of fresh leaves) should be consumed to cover the daily iron requirement. Vitamin $\mathrm{C}$ existing in parsley leaves improves iron intake in intestine. In this case examined leaves could be considered as an important source of iron for Trzebinia Commune inhabitants. Much lower Fe contents were determined in leaves of parsley sold in Poznań - they were from 28.0 to $191.1 \mathrm{mg} \cdot \mathrm{kg}^{-1} \mathrm{~d}$.m. with an average of $87.8 \mathrm{mg} \cdot \mathrm{kg}^{-1}$ d.m. (Bosiacki \& Tyksiński 2009). Harmanescu et al. (2011) present very high values of Fe contents $\left(2000 \mathrm{mg} \cdot \mathrm{kg}^{-1}\right.$ d.m.) in leaves of parsley grown in an old mining area located in Karpaty, in the west of Romania. The values are over 14 times higher than the ones determined in Trzebinia. However, in that case the iron contents in the soil were significantly higher, from a few to a dozen times.

It should be noticed that the proportion of the content of $\mathrm{Fe}$ in roots and leaves is similar. The indices of iron phytoaccumulation ranged from 0.02 to 0.027 (roots) and from 0.02 to 0.051 (leaves), which is a low degree of accumulation (Wiechuła et al. 2013). Łaszewska et al. (2007) presented a high degree of phytoaccumulation of this metal (26-751) for the tested herbs, which were common Saint-John's-wort, horse mint, common yarrow and common nettle grown in the Silesian and Żywiec Beskids. On the other hand the translocation indices of iron calculated for the tested parsley were high (1.04-5.25). In this case it indicates, this element is very easily transported from the roots to leaves. A high amplitude between the extreme Fe content values and even distribution of determined values within the range were noticed in the tested area. This might indicate significant differences in iron accumulation in parsley.

A high translocation of iron ( $\mathrm{TI}=0.5-1.6)$ in jatropha grown in wastelands contaminated with iron were determined by Ghavri et al. (2010). The iron contents in tested soil were from 1811-20 $663 \mathrm{mg} \cdot \mathrm{kg}^{-1}$ d.m. Comparable contents (400-144 $100 \mathrm{mg} \cdot \mathrm{kg}^{-1} \mathrm{~d}$.m.) with the average of $10700 \mathrm{mg} \cdot \mathrm{kg}^{-1} \mathrm{~d}$.m. were determined for soils in 
Lower Silesian Voivodeship by Kucharzewski \& Nowak (2004) and they recognized them as natural. Similar values of iron contents for soils in Wigierski, Świętokrzyski and Magurski National Parks were presented by Migaszewski et al. (2004). According to soil chemistry monitoring from 2010 to 2012 (Państwowy Monitoring Środowiska 2012) the iron content in Polish soils was from 1900-30 $130 \mathrm{mg} \cdot \mathrm{kg}^{-1} \mathrm{~d} . \mathrm{m}$. with the average of $9600 \mathrm{mg} \cdot \mathrm{kg}^{-1} \mathrm{~d} . \mathrm{m}$.

Researches have been carried out so far have not showed any essential lead functions in living organisms. There is no organism which needs lead in its life-processes. On the contrary, this element causes a number of ailments and it is especially harmful to infants and small children because it can cause irreversible changes in the central nervous system. Lead can also cause cardiovascular diseases, disorders in heme biosynthesis and vitamin D metabolism, kidney and liver dysfunctions, immune and reproductive system impairment, disorders of iron, copper and zinc metabolism (Cielecka \& Dereń 2011). According to Kabata-Pendias \& Pendias (2002) lead contents in plants range from trace amounts to $1 \mathrm{mg} \cdot \mathrm{kg}^{-1} \mathrm{~d} . \mathrm{m}$. The lead content in edible plants grown near industry areas, transport infrastructure or cities rises from the limit of natural content even up to $2.5 \mathrm{mg} \cdot \mathrm{kg}^{-1}$ d.m. (Finster et al. 2004, Zarzadzenie... 1993, Rozporzadzenie... 2003). The contents of this element in the tested parsley leaves ranged from $2.51-7.23 \mathrm{mg} \cdot \mathrm{kg}^{-1} \mathrm{~d} . \mathrm{m}$. and they were similar in case of roots $-2.56-7.45 \mathrm{mg} \cdot \mathrm{kg}^{-1} \mathrm{~d}$.m. Acceptable Daily Intake (ADI) of lead per an adult person is $50 \mathrm{ug} \cdot \mathrm{kg}^{-1}$ of body weight i.e. $3 \mathrm{mg}$ per an average person (Evaluation... 1987). The average lead content was $4.54 \mathrm{mg} \cdot \mathrm{kg}^{-1} \mathrm{~d}$.m. in leaves and $4.63 \mathrm{mg} \cdot \mathrm{kg}^{-1} \mathrm{~d}$.m. in roots, therefore $46-47 \mathrm{grams}$ of dry mass and adequately 203 grams of fresh root or 940 grams of fresh leaves can be safely consumed daily. The current Regulation of EU Commission (2011) concerning the highest allowable levels of some contaminations in foods gives the limit values in fresh mass. The values of $0.1 \mathrm{mg} \mathrm{Pb} \cdot \mathrm{kg}^{-1}$ f.m. for root vegetables and $0.3 \mathrm{mg} \mathrm{Pb} \cdot \mathrm{kg}^{-1} \mathrm{f}$.m. for leafy vegetables were established. After calculating to dry mass (Tab. 2), it is about $0.44 \mathrm{mg} \cdot \mathrm{kg}^{-1} \mathrm{~d}$.m. for root, whereas for leaves it is $1.90 \mathrm{mg} \cdot \mathrm{kg}^{-1} \mathrm{~d} . \mathrm{m}$. None of the contents in roots are close to the limit ones. The minimal value $2.56 \mathrm{mg} \cdot \mathrm{kg}^{-1} \mathrm{~d} . \mathrm{m}$. is about 5.8 times higher. The similar situation is in case of leaves. The minimum value $2.51 \mathrm{mg} \cdot \mathrm{kg}^{-1} \mathrm{~d}$.m. is 1.3 times higher. Szwalec \& Mundała (2012) evaluated the lead content in root vegetables grown in allotments in Kraków and the maximum value determined by these authors was not higher than $0.20 \mathrm{mg} \cdot \mathrm{kg}^{-1} \mathrm{~d} . \mathrm{m}$. in parsley root. Bosacki (2007) also is reporting high lead content in parsley being sold on Poznań market. The range for roots is $0.83-6.25 \mathrm{mg} \cdot \mathrm{kg}^{-1} \mathrm{~d} . \mathrm{m}$. with mean value equal $4.23 \mathrm{mg} \cdot \mathrm{kg}^{-1} \mathrm{~d} . \mathrm{m}$. In case of leaves the range is narrower $3.20-9.90 \mathrm{mg} \cdot \mathrm{kg}^{-1} \mathrm{~d} . \mathrm{m}$., concentration in Trzebinia Commune were lower. High variability of lead content in parsley leaves is reported by Figurska-Ciura et al. (2007). In her publication average lead contents in leaves of parsley grown in allotments in Legnica Cooper Belt were 4 times higher than the corresponding values determined in Opole and almost two times higher than the values in Wrocław however only one value exceeded the limit one.

According to the tests carried out as part of Soil chemistry monitoring (Państwowy Monitoring Środowiska 2012) the lead content in Polish soils fell within the scope of $5.60-965 \mathrm{mg} \cdot \mathrm{kg}^{-1}$ d.m., although the contents determined for $90 \%$ of collected samples were not higher than $32.09 \mathrm{mg} \cdot \mathrm{kg}^{-1} \mathrm{~d} . \mathrm{m}$. The lead contents in tested soil (Tab. 1) ranged from $48.72-218.92 \mathrm{mg} \cdot \mathrm{kg}^{-1} \mathrm{~d} . \mathrm{m}$. with the average of $88.67 \mathrm{mg} \cdot \mathrm{kg}^{-1} \mathrm{~d}$.m. Much higher contents of this metal (401.8-1723.4 mg.kg ${ }^{-1} \mathrm{~d} . \mathrm{m}$.) were determined in the village of Płoki (in Trzebinia Commune) by Mundała et al. (2005). The lead contents in soils of this area presented by Aleksander-Kwaterczak \& Ciszewski (2012) ranged from $43.3-8583 \mathrm{mg} \cdot \mathrm{kg}^{-1} \mathrm{~d} . \mathrm{m}$.

Accumulation of lead in roots and leaves did not occur. Only one sample had an average accumulation of 0.103 and 0.102 for leaves and roots respectively. In other cases the lead accumulation was low i.e. phytoaccumulation indexes were 0.01 to 0.1 . This relation is reflected in the calculated translocation indexes, which were similar $(0.90-1.12)$ in particular tests points.

\section{CONCLUSIONS}

1. Considering, there is a positive geochemical anomaly the lead contents in soil were low the average value was $88.67 \mathrm{mg} \cdot \mathrm{kg}^{-1} \mathrm{~d} . \mathrm{m}$. and only two contents -218.98 and 119.35 exceeded $100 \mathrm{mg} \cdot \mathrm{kg}^{-1} \mathrm{~d} . \mathrm{m}$. 
2. The lead contents in parsley roots and leaves were high, many times higher than the allowable values.

3. Lead phytoaccumulation indexes were low, only one had the average value, but at their minimal range (1.02 and 10.3 adequately for leaves and roots).

4. Translocation index of lead was close to one. The lead content in a thoroughly washed leaves was at the same level as in the roots. A decrease in the lead content in leaves in relation to roots, which is often citied, was not noticed.

5. The iron contents in soils were not high and they fell within the scope of low and average ranges that occur in Polish soils.

6. The iron contents in leaves were high, attractive from human or animal nutrition point of view.

7. The iron contents in roots were average so far nutrition, parsley root is a worse source of this element.

8. Phytoaccumulation index of iron in parsley leaves and roots was low.

9. Iron translocation index was high which confirms conclusions number 5 and 6 - the iron content in leaves was on average 2.8 times higher than in roots.

\section{REFERENCES}

Aleksander-Kwaterczak U. \& Ciszewski D., 2012. Zanieczyszczenie gleb na obszarze historycznej eksploatacji rud Zn- $\mathrm{Pb}$ (rejon Lgoty). Górnictwo i Geologia, 7, 2, 23-33.

Bielecka A., Ryłko E. \& Bojanowska I., 2009. Zawartość pierwiastków metalicznych w glebach i warzywach z ogrodów działkowych Gdańska i okolic. Ochrona Środowiska i Zasobów Naturalnych, 40, 209-216.

Bosacki M., 2007. The lead and cadmium content in edible parts of vegetables sold in the area of City of Poznań. Roczniki Akademii Rolniczej w Poznaniu. Ogrodnictwo, 41, 427-432.

Bosacki M. \& Tyksiński W., 2009. Copper, zinc, iron and manganese content in edible parts of some fresh vegetables sold on markets in Poznań. Journal of Elemento$\log y, 14,1,13-22$.

Cielecka E. \& Dereń K., 2011. Jakość żywności dla niemowląt i małych dzieci. Problemy Higieny i Epidemiologii, 92, 2, 187-192.

Commission Regulation (EU) No 420/2011 of 29 April 2011 amending Regulation (EC) 1881/2006 setting maximum levels for certain contaminants of foodstuff. Official Journal of the European Union L 111/3-L 111.6.

Evaluation of certain food additives and contaminants. Thirtieth report of the Joint FAO/WHO Expert Committee on Food Additives, 1987. WHO Technical Report Series, 751, World Health Organization, Geneva.
Figurska-Ciura D., Łoźna K. \& Styczyńska M., 2007. Cadmium, lead, zinc and copper selected vegetables and fruit from garden allotments of the south-western Poland. Polish Journal of Food and Nutrient Sciences, 57, 4(A), 137-143.

Finster M.E., Gray K.A. \& Binns H.J., 2004. Lead levels of edibles grown in contaminated residential soils: a field survey. The Science of the Total Environment Journal, 320, 2-3, 245-257.

Ghavri S.V., Singh R.P., 2010. Phytotranslocation of Fe by biodiesel plant Jatropha curcas L. grown on iron rich wasteland soil. Brazilian Journal of Plant Physiology, 22, $4,235-243$.

Harmanescu M., Alda M.L., Bordean D.M., Gogoasa I. \& Gergen I., 2011. Heavy metals health risk assessment for population via consumption of vegetables grown in old mining area; a case study: Banata County, Romania. Chemistry Central Journal, 5, 64.

Jędrzejczak R., 2004. Żelazo i mangan w żywności. Roczniki Państwowego Zakładu Higieny, 55, suplement, 13-20.

Kabata- Pendias A. \& Pendias H., 2002. Biogeochemia pierwiastków śladowych. Wydawnictwo Naukowe PWN, Warszawa.

Kiryk F. (ed.), 1994. Trzebinia, zarys dziejów miasta i regio$n u$. Wydawnictwo Secesja, Kraków.

Kucharzewski A. \& Nowak L., 2004. Żelazo i mangan w glebach ornych Dolnego Śląska. Roczniki Państwowego Zakładu Higieny, 55, suplement,105-111.

Lis J. \& Pasieczna A., 1995a. Atlas geochemiczny Polski 1:2500 000. Państwowy Instytut Geologiczny, Warszawa.

Lis J. \& Pasieczna A. 1995b. Geochemical atlas of Upper Silesia. Atlas geochemiczny Górnego Śląska 1:200 000. Państwowy Instytut Geologiczny, Warszawa.

Łaszewska A., Kowol J., Wiechuła D. \& Kwapuliński J., 2007. Kumulacja metali w wybranych gatunkach roślin leczniczych z terenu Beskidu Śląskiego i Beskidu Żywieckiego. Problemy Ekologii, 11, 6, 285-291.

Migaszewski Z.M., Gałuszka A., Michalik A. \& Pasławski P., 2004. Żelazo i mangan w glebach i skałach $\mathrm{z}$ wybranych Parków Narodowych - Magurskiego, Świętokrzyskiego i Wigierskiego. Roczniki Państwowego Zakładu Higieny, 55, suplement, 97-104.

Mundała P., Szwalec A., Telk M. \& Potz A., 2005. Szczegółowe określenie zawartości metali ciężkich $(\mathrm{Cd}, \mathrm{Pb}, \mathrm{Zn})$ w glebach dwóch obszarów gminy Trzebina wcześniej uznanych za silnie zanieczyszczone. Zeszyty Naukowe Akademii Rolniczej w Krakowie. Inżynieria Środowiska, 26, 417-424.

Ostrowska A., Gawliński S. \& Szczubiałka Z., 1991. Metody analizy i oceny właściwości gleb i roślin. Wydawnictwo IOŚ, Warszawa

Rozporzadzenie Ministra Zdrowia $z$ dnia 13 stycznia 2003 roku w sprawie maksymalnych poziomów zanieczyszczeń chemicznych i biologicznych. Dz. U. 2003 nr 37 poz. 325.

Państwowy Monitoring Środowiska. Monitoring chemizmu gleb ornych Polski. [on-line:] http://www.gios.gov.pl/ chemizm_gleb/index.php? $\bmod =$ wynikicz $=\mathrm{G}$ [access: 2014].

Szwalec A. \& Mundała P., 2012. Zawartość Cd, Pb, Zn i Cu $\mathrm{w}$ warzywach korzeniowych uprawianych w wybranych ogrodach działkowych Krakowa. Ochrona Środowiska i Zasobów Naturalnych, 53, 31-40. 
Śmiechowska M. \& Florek A., 2011. Content of heavy metals in selected vegetables from conventional, organic and allotment cultivation. Journal of Research an Applications in Agricultural Engineering, 56, 4, 152-156.

Wiechuła D., Doczekalska M. \& Pis A., 2013. Ocena fitokumulacji ołowiu i cynku w roślinach leczniczych z terenów pozyskiwania surowców zielarskich $\mathrm{w}$ województwie dolnośląskim. Bromatologia i Chemia Toksykologiczna, 46, 96-104.

Zarzadzenie Ministra Zdrowia i Opieki Społecznej z dnia 31 marca 1993 roku w sprawie wykazu substancji dodatkowych dozwolonych I zanieczyszczeń technicznych w środkach spożywczych i używkach. M.P. $1993 \mathrm{nr} 22$ poz. 233. 